\title{
Plants, People, and the Conservation of Biodiversity of Potatoes in Peru
}

\author{
Gregory J. Scott
}

CENTRUM Centro de Negocios, Pontificia Universidad Católica del Perú, Lima, Perú

\begin{abstract}
The conservation of biodiversity is of growing interest and concern worldwide. It is of particular interest in Peru, a country noted for the mega-diversity of its flora and fauna. Interest is especially high in the case of potato. The potato was first domesticated in Peru thousands of years ago and remains today the centrepiece of the diet, culture and rural economy in much of the highland region. The tremendous number of native potato varieties found within an array of ecologies is widely recognized by local and foreign scholars alike. This paper outlines the evolving portfolio of actors and their initiatives engaged in sustaining the potato's biodiversity in Peru. It highlights the complex set of diverse objectives and methods that the efforts of farmers, scientists, NGO staffers, and business managers entail as well as identifies key strengths and limitations of each. The paper then briefly articulates potential novel endeavors that have yet to be fully tested before laying out a series of pending initiatives aimed at increasing the synergy between and impact of the overall set of undertakings.
\end{abstract}

Key words: Native Varieties, Genebanks, ex situ, in situ, Non-governmental Organizations.

\section{Introduction}

Sustaining biodiversity in developing countries has been the focus of rising interest and concern over the last several decades (e.g., Ten Kate \& Laird 1999; Alteri \& Merrick 1987; Brush 2004; Bradshaw et al. 2006; Sutherland et al. 2009). The Food and Agriculture Organization (FAO) of the United Nations' declaration of 2010 as the International Year of Biodiversity is but the latest indicator of this trend. Along with continued technological advances in different scientific disciplines related to biodiversity, accelerating pressures (e.g. population, climate) on different ecologies, and the evolution of market forces, a highly dynamic and complex set of initiatives have emerged in which the types of individuals and organizations engaged in conservation activities have multiplied and become more diverse. Not all of these actors share the same views on what needs to be conserved, how best to do it, and who should be involved. In that context, exploiting opportunities for synergies if not complementarities between these different participants is frequently handicapped by incomplete information regarding who the different actors involved in these efforts are; what their respective approaches to biodiversity actually consist

\footnotetext{
${ }^{*}$ Send correspondence to: Gregory J. Scott

CENTRUM Centro de Negocios,

Pontificia Universidad Católica de Perú,

Jr. Alomia Robles, 125-129, Los Álamos de Monterrico,

Santiago de Surco Lima, 33, Perú

E-mail: gscott@pucp.edu.pe
}

of; where they are focusing their energies; what gaps might exist in the overall set of undertakings for a given set of biodiversity issues for particular species; or how knowledge and experience acquired by one type of actor might serve to enhance the performance of others and thereby facilitate more effective planning and execution of biodiversity efforts.

This paper presents a country/crop case study of the individuals and organizations engaged in biodiversity efforts; how their aims, methods, geographic focus, and resources have evolved over time; and, their respective strengths and limitations. Following Wale et al. (2009) and UNCED (1992), the term "biodiversity" refers here to the number, variety, and variability of plants (and the information contained therein) and the ecological complexes of which they are parts. By tracing out a typology of the evolving set of actors working on sustaining biodiversity, the paper puts forward a matrix reflecting efforts focused on both plants and people. In so doing, the paper seeks to provide a more holistic understanding of both past and on-going biodiversity efforts than those offered through emphasizing one particular approach (e.g., in situ conservation), or type of actor (e.g., scientists), or particular location (e.g., a given farm community) at a particular point in time. The intended outcome of such an exercise is to facilitate more informed and effective interaction among the different actors. At the same time, it seeks to offer a more meaningful framework from which to consider possible policy trade-offs in favor 
of one type of conservation (e.g., in situ) versus another (e.g., ex situ) (Wale et al. 2009) by making more explicit the different approaches to a given type of conservation. In the process, the paper sets out a framework that while focused on one particular crop, in one particular country might well be utilized for other organisms, in other locations where similar issues related to mapping the contribution of different actors involved in sustaining biodiversity could benefit from such an analysis.

\section{Biodiversity in Peru}

The conservation of biodiversity is of particular interest in Peru. The tremendous variability of climate, altitude, latitude, soils and typography together, make Peru home to a spectacular diversity of flora and fauna. Some 84 of the planet's 104 different major ecologies are said to be found within the country's borders (INIA \& MINAG 2002). The advent of the most recent technological innovations (i.e., transgenics), commercial rivalry with neighboring countries regarding the origin of products ranging from cherimoya to pisco, fears about the potential for illegal export of plant genes or patenting of indigenous knowledge by foreign corporations (Del Castillo 2004; Caillaux 2005), combined with concerns about the impact of climate change have generated widespread interest in and out of the country regarding what is being done to utilize and conserve Peru's biodiversity.

The potato is perhaps the most spectacular example of Peru's mega biodiversity. While in the late 1960s it was thought that Peru had some 1400 native potato varieties (Christiansen 1967), current estimates vary considerably. Tapia (2008a, p. 6) refers to 3,000 "[...] nominal varieties, that is with different local names." Risi (2009) mentions 3,800 native varieties. CIP (2009) refers to 2700 "endemic" native potatoes. Most recently, according to Alberto Salas, taxonomist at the International Potato Center (CIP), Peru is most likely home to between 2,000 and 2,500 native potato varieties. The higher numbers reported in recent years are partly due to a) the documentation of new materials collected or identified since then (Huaman \& Schmiediche 1999); and b) the development and use of more precise scientific methods for distinguishing between different accessions already held in different collections. It should also be noted that "native potato varieties" include both those few $(\mathrm{n}<20)$ native cultivars that have become commonplace in urban markets in contemporary Peru as well as the overwhelming majority of native varieties that traditionally are grown for on-farm consumption (and long-established practices of exchange between farmer communities) and only recently have begun to attract commercial interest.

Increased recognition of the potato as the fourth most important food crop in the global food system and it's growing importance in developing countries in particular (Scott et al. 2000; Guenthner 2001; Scott 2002; Devaux et al. 2010) has brought heightened attention worldwide to the maintenance of its biodiversity (Hijmans 2004; AAFC 2007) -- the Food and Agriculture Organization (FAO) of the United Nations declared 2008 as the International Year of the Potato. Interest in conserving the biodiversity of potatoes is particularly high in Peru. Recent research confirms Peru as the center of origin for this plant (Spooner et al. 2005). Furthermore, as Peru's most important food crop in terms of annual production and a source of livelihood and sustenance to some 600,000 farm families, the potato is of tremendous economic, social, nutritional, and cultural importance as well (Zimmerer 1996; Brush 2004; Chumpitaz 2008; Zegarra \& Tuesta 2008; DGCA \& MINAG 2009; Paredes Piana 2010; Rocha 2010).

Previous publications on the conservation of the biodiversity of potatoes in Peru have tended to focus on the micro-level (i.e., about a single organization, or in a specific community, or by a group of organizations or communities). Similarly, many of these earlier studies tended to discuss either ex-situ (e.g., Huaman \& Scmiediche 1999) or in situ conservation (e.g., Zimmerer \& Douches 1991; Zimmerer 1996; De Haan 2009), or work combining both (Tay 2009) emphasizing the botanical, biological, anthropological, or eco-geographical dimension of these efforts. More recent reports have examined pilot initiatives in which the sale and use of the tubers figure much more prominently (Ordinola et al. 2007a; Meinzen-Dick et al. 2009). Furthermore, much as in situ conservation has evolved over time (Brush 2004), technological change has broadened the mix of tools available to conserve potatoes ex situ (CIP 2009). Similarly, the socio-economic environment has generated new wants opening up marketing outlets for new uses and new opportunities for conserving native varieties through different schemes involving an ever-expanding array of commercial partnerships (Ordinola et al. 2007a).

Given this situation, this paper analyzes the activities of the growing diversity of actors or organizations engaged in some aspect of the conservation of the biodiversity of potatoes under four broad headings-farmers, scientists, Non-Governmental Organizations (NGOs), and commercial enterprises. In synthesizing journal articles, books, and student theses as well as project reports, monographs, and conference presentations, the paper examines the origins of these different actors' respective conservation efforts as well as their objectives, methods, strengths and limitations in an effort to capture the dynamism of their on-going activities. While readily acknowledging that some actors of each type increasingly work together in a variety of partnerships or alliances, the paper seeks to place in sharper relief their particular uniqueness, complementarities, and potential areas of synergy as well as disagreement. The resulting matrix then facilitates delineating a series of pending initiatives in the concluding remarks.

\section{Farmer-led Conservation}

For centuries, small farmers in the Andean highlands have maintained the biodiversity of the potato in their own fields, 
or in situ. The principal objective of these farmers has been and continues to be preserving their annual source of food as well as the cultural traditions and beliefs that potato cultivation and use represents for them, their families, and farm communities rather than diversity as an end in itself (Tapia 1994; Zimmerer 1996; Brush 2004). Maintaining a diverse collection of cultivated native varieties, some more resistant to certain biotic or abiotic constraints, some more appropriate for certain end uses or prized for particular culinary traits, was and is their way of pursuing these objectives (Tables 1 and 2).

Traditionally, these farmers have used an array of conservation activities. These include crop rotations, seed rotations, seeding patterns, and the exchange of seed. They also involve their accumulated knowledge and experience -- passed on from generation to generation, gained from working with these varieties alongside other farmers in their own or similar communities as a means to maintain biodiversity (Brush et al. 1992; Tapia \& Rosas 1993; PRATEC 1997; Brush 2004).

As Brush (2004) observes, Andean--like all--agriculture has never been a static system, but beginning around 1900 the pace of change began to accelerate. Over the last several decades in particular, agricultural production in the highlands has become more market-oriented. Various factors have contributed to this trend. Peru's population went from $52 \%$ urban in 1963 (Herrera et al. 1994) to $76 \%$ urban in 2007 , from $65 \%$ living in the highlands $(1,500-4,000 \mathrm{~m})$ in 1940 to $55 \%$ living on the coast in 2007 . At the same time, Peru grew from seven million inhabitants in 1940 to over 28 million in 2007 (Maximixe 2008). Beginning in the 1990s, government policy shifted towards privatization of public enterprises, liberalization of the domestic economy, and an aggressive pursuit of free trade agreements (Hausmann \& Klinger 2006; Murakami 2007). Road building and telecommunications networks have expanded at a high rate in recent years (Proexpansión 2008). With the spread of commercial agriculture into heretofore relatively isolated highland production centers, field research in the 1980s documented the incidence of genetic erosion among some potato producers (Brush et al. 1992). The diffusion of higher-yielding varieties developed and adopted in an effort to meet growing urban food demand and lower per unit production costs induced some small highland producers to reduce the number of varieties planted, mainly due to displacement (Zimmerer 1996; Brush 2004). Moreover, Mayer (2002) found that some small growers who continued to plant native potatoes only took account of their cash costs, i.e. not including the cost of non-purchased inputs such as their own household labor. By doing so, they failed to fully appreciate that their economic losses in potato production acted as a sort of subsidy to the continued cultivation, hence conservation, of native potato varieties and the source of genes needed to help sustain Peru's and the world's supply of this basic commodity. But the process was and is uneven, and complex. For some small farmers, the introduction of new hybrid varieties simply adds to the existing gene pool such that cultural, economic, and environmental factors together continue to buffer the impact of new varieties on biodiversity (Brush 2004). More importantly, perhaps, these latter findings suggested the elements that might be reinforced in support of on-going conservation efforts undertaken by small farmers that are increasingly recognized as the cornerstone of sustaining biodiversity of potatoes in Peru.

Notwithstanding the growing interest in and increased recognition of farmers' critical role in the maintenance of

Table 1. Conservation of biodiversity of potatoes in Peru: Actors, origins, focus, objectives, and time horizon.

\begin{tabular}{|c|c|c|c|c|}
\hline Actors & Origin & Focus & Objectives & Time horizon \\
\hline Farmers & Millenia & Local & $\begin{array}{c}\text { Food security, maintenance } \\
\text { traditional way of life }\end{array}$ & $\begin{array}{l}\text { Short-term to } \\
\text { maintain long-term }\end{array}$ \\
\hline $\begin{array}{l}\text { Scientists \& } \\
\text { research } \\
\text { organizations }\end{array}$ & $1920 \mathrm{~s}$ & $\begin{array}{l}\text { Regional, national \& } \\
\text { international }\end{array}$ & $\begin{array}{l}\text { Maintain collections of native varieties } \\
\text { for access to the genes, develop new } \\
\text { improved potato varieties, research } \\
\text { results; enhance food security; } \\
\text { erradicate poverty }\end{array}$ & Medium- to long-term \\
\hline NGOs & $1930 \mathrm{~s}$ & Local \& regional & $\begin{array}{l}\text { Promote production, use, conservation } \\
\text { of native varieties, local knowledge } \\
\text { culture; income gains; poverty reduction }\end{array}$ & $\begin{array}{l}\text { Short-term (Project life) to } \\
\text { maintain long-term }\end{array}$ \\
\hline $\begin{array}{l}\text { Stewards } \\
\text { (Conservacionistas/ } \\
\text { cuidadores) }\end{array}$ & $1980 \mathrm{~s}$ & $\begin{array}{l}\text { Local \& } \\
\text { regional }\end{array}$ & $\begin{array}{l}\text { Food security, promotion of their } \\
\text { materials, additional income through } \\
\text { more formalized associations } \\
\text { with other farmers or alliances with } \\
\text { other actors }\end{array}$ & $\begin{array}{l}\text { Short-term } \\
\text { maintain long-term }\end{array}$ \\
\hline Companies & $1990 \mathrm{~s}$ & $\begin{array}{l}\text { Regional, national \& } \\
\text { international }\end{array}$ & $\begin{array}{c}\text { Generate profits, good will, corporate } \\
\text { social responsibility, assist } \\
\text { maintenance of local biodiversity }\end{array}$ & Short-to medium-term \\
\hline
\end{tabular}


Table 2. Conservation of biodiversity of potatoes in Peru: Actors, activities, strengths and limitations.

\begin{tabular}{|c|c|c|c|}
\hline Actors & Activities & Strengths & Limitations \\
\hline Farmers & $\begin{array}{l}\text { Plant \& harvest potatoes, in } \\
\text { multiple plots in different } \\
\text { ecologies, seed exchange, crop } \\
\text { rotations, exchange knowledge } \\
\text { and experience about potato } \\
\text { varieties at the community level }\end{array}$ & $\begin{array}{l}\text { Accumulated inter-generational } \\
\text { knowledge about agronomic, } \\
\text { postharvest, culinary varietal traits, } \\
\text { local growing conditions }\end{array}$ & $\begin{array}{l}\text { Natural hazard, natural or } \\
\text { man-made disaster risk; } \\
\text { scarce technical \& financial } \\
\text { resources; limited technical } \\
\text { expertise; focus on cultivated } \\
\text { species; limited contact with } \\
\text { more distant communities } \\
\text { that also have native varieties }\end{array}$ \\
\hline $\begin{array}{l}\text { Scientists \& research } \\
\text { organizations }\end{array}$ & $\begin{array}{l}\text { Research involving collection, } \\
\text { characteriz-ation and cleaning } \\
\text { of native varieties, plant } \\
\text { breeding; experiments in lab and } \\
\text { field plots; preservation through } \\
\text { various procedures including } \\
\text { out planting, storage in the form } \\
\text { true seed, etc. Support services } \\
\text { to growers (e.g., providing } \\
\text { clean planting material), farm } \\
\text { communities and organizations } \\
\text { (universities, MINAG, INIA) }\end{array}$ & $\begin{array}{l}\text { Technical expertise \& infrastructure, } \\
\text { financial \& human resources; } \\
\text { contacts with technical expertise } \\
\text { and gene banks around the world; } \\
\text { mobility to contact multiple } \\
\text { communities in given time period }\end{array}$ & $\begin{array}{c}\text { Emphasis on ex-situ vs in situ } \\
\text { conservation, breeding } \\
\text { processes that take years to } \\
\text { produce varieties, then years } \\
\text { to reach farmers' fields }\end{array}$ \\
\hline NGOs & $\begin{array}{l}\text { Tech assistance, training in best } \\
\text { conservation practices; facilitate } \\
\text { exchange of native varieties; } \\
\text { creation of community-based } \\
\text { gene depositories; repatriation } \\
\text { of planting material of varieties } \\
\text { collected in communities; } \\
\text { technical assistance in } \\
\text { developing new and/or } \\
\text { improved products }\end{array}$ & $\begin{array}{l}\text { Contacts with local farmer } \\
\text { communities, flexibility to } \\
\text { work on different aspects of } \\
\text { the food system, knowledge of } \\
\text { constraints farmers face to sustain } \\
\text { their livelihoods, experience in } \\
\text { field projects for ag-led rural } \\
\text { development }\end{array}$ & $\begin{array}{l}\text { Limited financial resources; } \\
\text { limited experience \& } \\
\text { technical expertise in } \\
\text { commercial, business-related } \\
\text { activities; efforts restricted by } \\
\text { time, place, purpose, funding } \\
\text { availabilty for particular } \\
\text { project(s) }\end{array}$ \\
\hline $\begin{array}{l}\text { Stewards } \\
\text { (Conservacionistas/ } \\
\text { cuidadores) }\end{array}$ & $\begin{array}{l}\text { All of framers'activities listed } \\
\text { above \& participation in local } \\
\text { \& regional fairs and events to } \\
\text { exchange or diffuse their native } \\
\text { varieties, gain access to other } \\
\text { native varieties }\end{array}$ & $\begin{array}{l}\text { Are more mobil and have more } \\
\text { resources than the average grower } \\
\text { to facilitate travel to wider range } \\
\text { of locations for seed exchange and } \\
\text { sharing knowledge about native } \\
\text { varieties about }\end{array}$ & $\begin{array}{l}\text { Limited financial resources; } \\
\text { limited technical expertise; } \\
\text { limited accountability } \\
\text { and geographic scope of } \\
\text { activities }\end{array}$ \\
\hline Companies & $\begin{array}{c}\text { Process and sell potato products } \\
\text { made from native potato } \\
\text { varieties }\end{array}$ & $\begin{array}{l}\text { Offer higher prices and incomes } \\
\text { from native potatoes; financial } \\
\text { resources to make long-term } \\
\text { investments in developing markets }\end{array}$ & $\begin{array}{l}\text { Interest limited to most } \\
\text { appropriate native varieties } \\
\text { for processing and locations } \\
\text { most conducive to generating } \\
\text { profits }\end{array}$ \\
\hline
\end{tabular}

the potato's biodiversity in Peru (Zimmerer 1996; Brush 2004; De Haan 2009), some observers have long pointed out the precarious nature and limited resources associated with highland potato production and the limitations of in situ conservation as a result (Table 2). As potatoes are overwhelmingly a rain-fed crop, surveys of farm households in particular communities recurrently found evidence of local adverse weather severely affecting the potato crop (Scott 1985; Antezana et al. 2005). The added risk of a climatic disaster, e.g., the severe drought in the southern highlands during El Niño of 1983 (or the flooding near Cusco in 2010), associated with potato cultivation in a given growing season combined with terrorist activities in the rural highlands in the 1980s and early 1990s led to a renewed call for ex situ conservation as a form of insurance against both natural and man-made disaster (Huaman \& Schmiediche 1991). As De Haan notes (2009), population pressure resulting in reduced fallow periods and penetration of regular production into higher altitude growing areas once largely confined to pasture combined with climate change are likely to increase the levels of weather-related stress on in situ conservation. Alternatively, labor shortages in one isolated community led to the loss of potato cultivars (Brush 2004) as have shifting use patterns contributed to apparent the loss of one species in a group of eight highland communities (De Haan 2009). Moreover, with few notable exceptions (Brush 2004; De Haan 2009) in situ conservation largely, if not exclusively, focuses on cultivated potatoes with little, if any, mention of wild species or what could be done to enhance their chances of avoiding extinction through a random act of nature or the expansion of human activity into heretofore isolated habitat. Huaman \& Schmiediche (1991) have also noted that the annual costs of maintaining native potato varieties is prohibitively expensive and therefore requires the type of sustained financing and technical expertise most frequently found at the institutional level. 
In addition, according to plant breeder Prof Humberto Mendoza at Peru's National Agricultural University at La Molina (UNALM), what is truly important is the use of particular genes found in native varieties in the process of varietal improvement for the benefit of a much larger group of producers and consumers.

\section{Scientist-led Conservation}

Beginning in the early 1900s, various researchers based in organizations in Peru-local, regional, national and international-have employed different strategies both to conserve and exploit the biodiversity of Peru's native potato varieties both on and off (i.e., ex situ) the farm (Table 1). The Experiment Station in La Molina, now a suburb of the capital, was established in the late 1920s. Its initial program of work included crosses of native potato varieties with material brought from Mexico (Christiansen 1967). A Czech-born, Salesian priest Jaroslav Soukup living near Puno began characterizing native potato varieties in the late 1930s (Tapia 2008a). By the late 1940s, the Ministry of
Agriculture had become formally constituted as a separate entity, no longer part of the Ministry of Public Works, and began breeding work involving native potato varieties in the highlands (Christiansen 1967). In 1952, Carlos Ochoa, with the support of the Rockefeller Foundation, travelled to northern Peru collecting material that was subsequently deposited at the Ministry of Agriculture's Experiment Station in the Mantaro Valley (Figure 1) in the central highlands and helped start the national germplasm collection (Ochoa 1955). About that same time, Prof. Ochoa crossed two andigenum native varieties and developed Renacimiento, a hybrid variety that eventually became the most widely grown commercial variety in Peru (Graber 1974). By the early 1960 s, the national potato improvement program was launched, along with those for several other major agricultural commodities, as part of the national agricultural production and extension service. By the mid-1960s, the national potato program included a germplasm bank with a reported 1,400 native potato varieties collected from all over the country (Christiansen 1967).

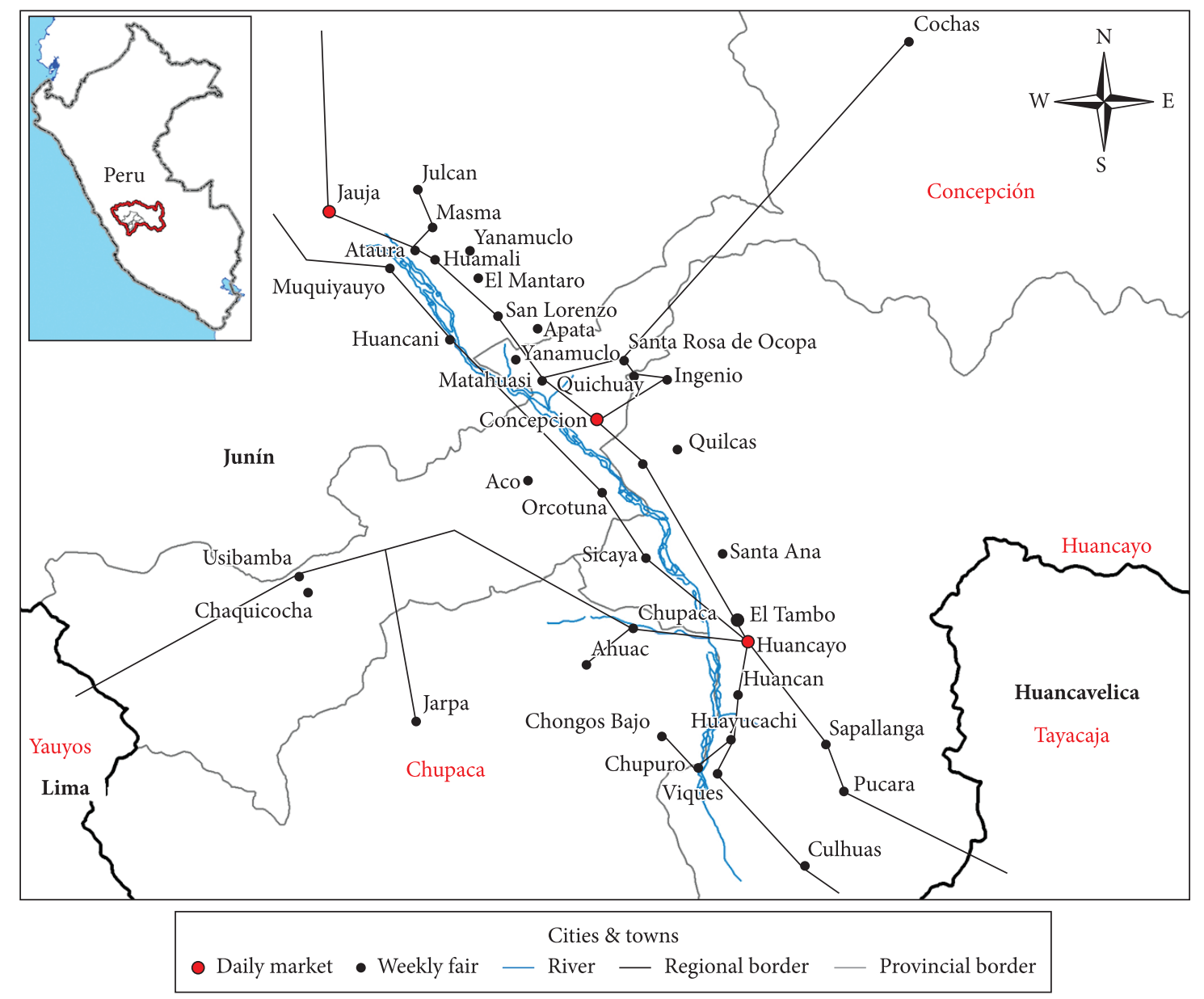

Figure 1. Peru: The Mantaro Valley in the Central Highlands. 


\section{University-based researchers}

By 1965, Prof. Ochoa was full-time at UNALM and had launched the university's own Potato Research Program. He also began building up the university's own germplasm bank from collection expeditions undertaken in different parts of Peru. In more recent years, UNALM's conservation activities have largely consisted of backstopping efforts of selected growers to maintain their collections in highland production centers such as Huánuco (Egúsquiza et al. 2006; DGCA \& MINAG 2009) and Apurimac as well as providing materials from its collection as genes for the national breeding effort carried out by the National Potato Program housed within Peru's national agricultural research institute (Risi 2009). UNALM maintains its 377 accessions of native potatoes from around Huánuco and the 68 from Apurimac at its Instituto Regional de Desarrollo/ Experiment Station at Yanamuclo near Jauja in the Mantaro Valley in the central highlands (Figure 1). Several other universities in Peru-Cerro de Pasco, Cusco, Huancayo, and Puno, also maintain tissue culture labs and field plantings of native potato varieties of local origin as part of their research and conservation efforts. Other universities such as the Universidad Nacional de Cajamarca and San Cristobal de Huamanga in Ayacucho used to have collections of native potatoes, but a combination of terrorist activities in the 1980s and early 1990s, budget cuts, staff changes, and the prohibitive cost of continued maintenance led to their decline and in some cases eventual collapse. In addition, a number of universities have also supported and/or complemented conservation efforts through research on: i) characterization of native varieties for particular culinary, medicinal, or nutritional properties (Segura 2002, Mayer et al. 2005; Barbier 2009); ii) production and marketing systems (Pilares 1993; Almeyda Camani 2004); iii) ethnobotany (Urrunaga 2002); and iv) feasibility studies for new business ventures based on native potatoes (De la Piedra et al. 2004; Chiu \& Guevara 2005; Canora et al. 2007; Meléndez Simoni et al. 2008; Fuentes et al. 2009) to mention but a few disciplines, with these studies nearly always modest in scope or subject to the availability and vicissitudes of external funding.

\section{National Institute for Technological Innovation}

Since the 1960s, the National Potato Program has been part of the National Institute for Agricultural Innovation (INIA). As a semi-autonomous organization within the Ministry of Agriculture (MINAG), INIA's responsibilities and corresponding acronym have frequently changed over the last fifty years. Launched as the Agricultural Research and Extension Service in the 1960s, INIA became the National Institute for Agricultural Production in 1981, then the National Institute for Agricultural and Agro-industrial Research in 1986, the National Institute for Agricultural Research in 1992, the National Institute for Agricultural Research and Extension in the late 1990s, then back to the National Institute for Agricultural Research in 2006, and then to its most recent title in 2009. INIA currently maintains a decentralized collection of native potato varieties at its five experiment stations in the highlands: Ayacucho (Canaan), Cajamarca (Baños del Inca), Cusco (Andenes), Huancayo (Santa Ana) and Puno (Illpa). These materials are maintained through annual field plantings and in vitro. In Ayacucho, for example, INIA scientists have been working with CIP staff in evaluating the 650 accessions maintained at the Canaan Experiment Station (Morote et al. 2009). Along with populations of hybrids received from CIP and native materials from UNALM, INIA's own collections provide the germplasm for INIA's potato breeding efforts tailored to regional as well as national varietal requirements.

Over the last 30 years, INIA has released a number of varieties developed from native materials (Risi 2009). INIA recently participated in efforts to register 61 native potato varieties with the National Agricultural Product Health Service (SENASA) so that these varieties could be legally eligible for use in the production of certified seed (Gómez et al. 2008). As noted by Manuel Sigueñas Director Research of INIA, MINAG's registration procedures for seed certification are designed for newly released or imported varieties, not cultivars grown in Peru for milennia. Such registration involves preparation of a technical, quasi-legal document that establishes that the variety is new, who it is owned or has been released by, what its (superior) agronomic, culinary and nutritional traits are as well as its adoptability to different growing conditions. Hence, registration implies field trials and laboratory analyses with their associated costs. These efforts are intended to ensure that if registered and certified seed are produced, the planting material meet growers' expectations once cultivated in their fields. As such, native potato varieties that belong to no particular organization or that may be found in several different farm communities create challenges not contemplated in the original design of registration procedures linked to certified seed production.

For several years INIA has also served as home to the Investigación y Competividad para el Agro Peruano (INCAGRO) project, a nation-wide system of competitive grants covering all agricultural commodities. Over the last decade INCAGRO's project portfolio has included a number of research and development projects focused on the conservation, characterization, production and marketing of native potato varieties (see, e.g., UNALM 2009). In addition, INIA has been engaged compiling a unified national data base containing information about the native potato varieties that are held in the collections of its experiment stations, the different universities and by the NGOs, among other reasons, to reduce, where possible, the number of duplicate accessions and the cost of maintaining the various collections. Over the years INIA's conservation efforts have been handicapped by a shifting mandate-from research to research and extension, and then to innovation; recurrent staff changes and personnel cuts; reallocation of infrastructure-- in the 1990s, INIA's experiment stations was 
shifted to universities and the private sector, then efforts were made to take that control back the following decade; and uncertainty over annual operating budgets and the periodic allotment of funds related to them during any given financial year by the Ministry of Agriculture.

\section{International Potato Center (CIP)}

CIP was founded in 1971. From its inception, CIP has sought to collect, classify, preserve, evaluate and distribute potato germplasm as part of its responsibility to preserve endangered potato genetic resources for future generations and to ensure access to these genes for breeders around the world but particularly in developing countries (CIP 1990; Huaman \& Schmiediche 1999). CIP's conservation efforts related to native potato varieties began when it inherited a Peruvian germplasm bank consisting of some 1,800 entities (CIP 1972). In addition, CIP scientists carried out a series of collection expeditions in the highlands of Peru (as well as Bolivia, Colombia, Ecuador, Guatemala and Mexico) to procure both wild and cultivated potatoes (Bradshaw et al. 2006). The resulting World Potato Collection, the largest of its kind found anywhere on the planet, includes 2700 endemic native cultivated potato varieties from Peru plus another 900 from Bolivia and Ecuador (CIP 2009) and is held in trust at CIP "[...] as part of an international effort to prevent genetic erosion and losses, to secure worldwide access to these resources, and to use then in breeding to increase potato productivity" (Huaman \& Schmiediche 1999, p. 415).

Initially, CIP maintained its germplasm in both botanical seed and clonal form (CIP 1972). Methods for conservation of genetic resources that have been developed over time for botanical, technical, and economic reasons (Huaman \& Schmiediche 1999) include tissue culture, microtuber conservation and cryo-conservation (Mix-Wagner 1999). CIP currently employs all five methods as well as frozen DNA in the technical component of its germplasm conservation strategy. It also manages the first genebank in the world to obtain ISO 17025 accreditation (CIP 2009).

The overwhelming emphasis in CIP's germplasm conservation activities over the years has been on, but not restricted to, ex situ conservation. CIP scientists have maintained most part of the Center's accessions ex situ in vivo by replanting every year at CIP's experiment station outside Huancayo in the Mantaro Valley (Figure 1). Many accessions are also held ex situ in vitro at CIP headquarters in Lima. In addition, since 1998 CIP scientists have also become more deliberately engaged in support of in situ conservation (Tay 2009). Up to now these efforts have focused largely on working with farmers' communities located near Cusco. CIP has been providing these growers with clean, virus-free native cultivars as well as information about improved production practices gleaned from their experience interacting with small farmers in the Andean highlands over the last 40 years. CIP plans are to expand these in situ activities in the years ahead to include a number of other highland farm communities noted for their concentration of native potato varieties (Ibid.). In addition, according to CIP's Rene Gómez, since 1998 the Center has repatriated more than 3,600 high quality samples of more than 1200 varieties of native 'potatoes to over 40 Andean farm communities in 12 regions of Peru.

Following its decentralized strategy for its other research and development activities, CIP's conservation efforts have also long included promotion of collaboration between potato genebanks around the world (Huaman \& Schmiediche 1999; Bradshaw et al. 2006) and the utilization of alternative conservation sites as back-up locations for its germplasm collection that includes native potato varieties from Peru. The principal potato collections held outside Peru are the Commonwealth Potato Collection (CPC, Dundee, Scotland), the Dutch-German Potato Collection (CGN, Wageningen, the Netherlands), the Groß Lusewitz Potato Collection (GLKS, IPK, Groß Lusewitz, Germany), the Potato Collection of the Vavilov Institute (VIR, St Petersburg, Russia), and the US Potato Genebank (NRSP-6, Sturgeon Bay, USA). These collections together with those held by CIP, by the Instituto Nacional de Tecnologia Agropecuaria (INTA) in Argentina and the Instituto Boliviano de Tecnologia Agropecuaria (IBTA) in Bolivia constitute the Association for Potato Intergenebank Collaboration. In the 90's, alternative sites for all or part of the World Potato Collection maintained by CIP included the Instituto Nacional Autónomo de Investigaciones Agropecuarias (INIAP) in Quito, Ecuador (it no longer maintains CIP material) and the National Seed Storage Laboratory in Ft Collins, USA. Currently, CIP's World Potato Germplasm Collection is not only maintained in Peru but also at the new "doomsday" seed vault located in a cave in the ice on the island of Svalbard, Norway (See http:// www.scientificamerican.com/blog/60-second-science/post. cfm?id=doomsday-vault-aims-to-save-the-wor-2009-02-27) near the Arctic Circle and in duplicate for conservation only at INTA Balcarce, Argentina.

Over the years, various observers have called attention to the limitations of ex situ conservation (Table 2). They point out that germplasm in the cradles of diversity are not frozen in time, but continue to evolve in response to changing conditions in the habitat where they exist (Alteri \& Merrick 1987; Brush 1992). Hence, sustaining such natural evolution is critical to maintaining their vibrancy and robustness as gene depositories. Yet, ex situ collections are linked to their collection dates when new varieties may have appeared since then due to " $[. .$.$] mutation, recombination, gene flow$ between wild, weedy and cultivated populations [...]" (Brush 2004, p. 199). Nevertheless, since implementation of the convention on biodiversity in the early 1990s (UNCED 1992), expeditions such as those carried out in the past to enable ex situ conservation are subject to regulations that are interpreted differently by different public organizations effectively inhibiting collection of genetic resources in the form of plants and the local knowledge embodied therein. As Brush (2004) notes, for example, INIA has had one 
set of procedures governing permits for collecting plant material and the National Institute for Natural Resources (INRENA) another. Furthermore, others contend that what needs to be conserved are not simply the plants, but also the local people's knowledge about native potatoes passed on over generations before it too is lost (Prain 1993). Ex situ collections involve passport data for each accession that typically lack that information. Furthermore, critics contend, ex situ conservation does little to redress the inequities resulting from the use of native germplasm in varietal development to generate value-added relatively little of which has accrued to poor, small farmers in locations where the native materials were first collected.

\section{NGO-supported Conservation}

Non Governmental Organizations (NGOs) have been involved with the conservation of Peru's native varieties in myriad ways for decades. For example, by the late 1990s, CIP had received over 500 accessions from Peruvian NGOs of which over 100 new cultivars were identified (Huaman \& Schmiediche 1999). However, not all NGOs share the same views on how, let alone how best, to achieve the conservation of the biodiversity of native potato varieties. NGOs' efforts range from working with farmers on in situ conservation focused on organic production techniques and the best traditional practices, to the incorporation of chemical inputs to raise yields and improve grade outs so as to raise incomes from the sale of native potatoes, to promotion and advocacy work with local, regional, and national governments (Tables 3 and 4). Given their often-strong community focus and limited resources, most NGOs tend to work in particular locations on particular initiatives using different approaches. Thus, for example, the NGO Centro IDEAS in Cajamarca is working with local small growers on the in situ conservation of over 130 native varieties by supporting their efforts to document and utilize local native potatoes, appropriate traditional cultivation techniques and local knowledge systems. NGOs

Table 3. Non-Governmental Organizations (NGOs) engaged in conservation of biodiversity of native potatoes in Peru.

\begin{tabular}{|c|c|c|c|c|}
\hline NGO & Established & Link & Regional focus/Office & Activities \\
\hline ADERS-Peru $^{1}$ & 2003 & www.aders-peru.org & $\begin{array}{l}\text { Cajamarca, Huanuco } \\
\text { Huancavelica, Pasco, } \\
\text { Ica }\end{array}$ & $\begin{array}{l}\text { Credit, technical assistance, product } \\
\text { and market development, support } \\
\text { to growers' organizations }\end{array}$ \\
\hline ANDES $^{2}$ & 1995 & www.andes.org.pe & Cusco & $\begin{array}{l}\text { Support for traditional practices, } \\
\text { repatriation native varieties, expansion } \\
\text { of local markets for native potatoes, } \\
\text { local knowledge networks }\end{array}$ \\
\hline ARARIWA $^{3}$ & $1986^{\mathrm{a}}$ & www.arariwa.org.pe & Cusco & $\begin{array}{l}\text { Support traditional practices via education, } \\
\text { publications, technical assistance, marketing }\end{array}$ \\
\hline CAPAC-Peru ${ }^{4}$ & 2003 & www.capacperu.org & Cusco & $\begin{array}{l}\text { Technical assistance in production } \\
\text { contract negotiation/ compliance for } \\
\text { sales to industrial processors }\end{array}$ \\
\hline Centro IDEAS ${ }^{5}$ & $1978^{\mathrm{a}}$ & www.ideas.org.pe & Cajamarca & $\begin{array}{l}\text { Promotion of organic agriculture, } \\
\text { sale, consumption of organic products }\end{array}$ \\
\hline CCTA $^{6}$ & 1984 & www.ccta.org.pe & Lima & $\begin{array}{l}\text { Focused on agronomy of conservation; } \\
\text { information hub, training work } \\
\text { done in alliance with smaller NGOs }\end{array}$ \\
\hline $\mathrm{CESA}^{-\mathrm{Cusco}^{7}}$ & n.a. ${ }^{a}$ & www.cesa.cusco.org.pe & Cusco & $\begin{array}{l}\text { Support for agronomic, cultural traditions, } \\
\text { local knowledge for conservation }\end{array}$ \\
\hline $\mathrm{CICDA}^{8}$ & 1977 & www.avsf.org & Huancavelica & $\begin{array}{l}\text { Technical assistance for production, } \\
\text { processing \& sale of potato chips via } \\
\text { Fair Trade network, certification }\end{array}$ \\
\hline
\end{tabular}

${ }^{1}$ Associacion para el Desarrollo Sostenible; ${ }^{2}$ Quechua-Aymara Asociación for Nature and Sustainable Development; ${ }^{3}$ Asociacion Arariwa para la Promoción Técnica Cultura Andina; ${ }^{4}$ Cadenas Productivas Agrícolas de Calidad; ${ }^{5}$ Investigación, Documentación, Educación, Asesoramiento y Servicios; ${ }^{6}$ Coordinadora de Ciencia y Tecnología de los Andes; ${ }^{7}$ Centro de Servicios Agropecuarios; ${ }^{8}$ Centro Internacional de Cooperación para el Desarrollo. ${ }^{a}$ Associated with CCTA in in situ projects. 
Table 4. Non-Governmental Organizations (NGOs) engaged in conservation of biodiversity of native potatoes in Peru.

\begin{tabular}{|c|c|c|c|c|}
\hline NGO & Established & Link & $\begin{array}{c}\text { Regional focus/ } \\
\text { Office }\end{array}$ & Activities \\
\hline CIRNMA $^{1}$ & 1992 & www.cirnma.galeon.com & Puno & $\begin{array}{l}\text { Tecnical assistance, product/market } \\
\text { develop-ment for processed products, } \\
\text { support to growers' organizations }\end{array}$ \\
\hline FOVIDA $^{2}$ & $1984^{\mathrm{a}}$ & www.fovida.org.pe & Huancavelica, Junin & $\begin{array}{l}\text { Technical assistance, training to farmer } \\
\text { com-munities in production of seed, } \\
\text { potatoes for processing, negotiation/ } \\
\text { implementation of contracts with } \\
\text { processors }\end{array}$ \\
\hline IDMA -Peru ${ }^{3}$ & $1984^{\mathrm{a}}$ & www.idmaperu.org & $\begin{array}{c}\text { Ancash, Apurimac, } \\
\text { Huanuco, Lima }\end{array}$ & $\begin{array}{c}\text { Technical assistance, training in production } \\
\text { without chemical inputs, promotion } \\
\text { of policies at regional, national level in } \\
\text { support of small farmers and sustainable } \\
\text { development }\end{array}$ \\
\hline $\begin{array}{l}\text { Instituto Rural } \\
\text { Valle Grande }\end{array}$ & 1965 & irvg@terra.com.pe & Cañete, Yauyos & $\begin{array}{l}\text { Training, technical assistance in support } \\
\text { of in situ conservation emphasizing } \\
\text { ecologically friendly production practices }\end{array}$ \\
\hline ITDG $^{4}$ & $1985^{\mathrm{b}}$ & www.itdg.org.pe & Cusco & $\begin{array}{c}\text { Training in improved production practices; } \\
\text { technical assist in marketing native } \\
\text { potatoes }\end{array}$ \\
\hline PRATEC $^{5}$ & 1986 & www.pratec.org.pe & Lima & $\begin{array}{c}\text { Support for agronomic, cultural traditions, } \\
\text { local knowledge for in situ conservation; } \\
\text { technical training; hub for exchange } \\
\text { of information, strategic alliances with } \\
\text { smaller NGOs }{ }^{c}\end{array}$ \\
\hline SPDA $^{6}$ & 1986 & www.spda.org.pe & Lima & $\begin{array}{l}\text { Technical assistance with conservation } \\
\text { projects, publications, information-- } \\
\text { promotion of laws and policies at regional, } \\
\text { national level in support of environmental } \\
\text { conservation }\end{array}$ \\
\hline $\begin{array}{l}\text { Grupo- } \\
\text { TALPUY }\end{array}$ & 1978 & g-talpuy@amautua.rcp.net.pe & Junin, Huancavelica & $\begin{array}{l}\text { Training, technical assistance in support of } \\
\text { in situ conservation using farmer-based } \\
\text { technologies and practices }\end{array}$ \\
\hline Urpichallay & n.a. ${ }^{c}$ & urpi@telematic.edu.pe & Huaraz & $\begin{array}{c}\text { Support for agronomic, cultural traditions, } \\
\text { local knowledge aspects of in situ } \\
\text { conservation }\end{array}$ \\
\hline $\begin{array}{l}\text { Grupo } \\
\text { Yanapai }\end{array}$ & 1982 & www.gyanapai.org & Junin, Concepcion & $\begin{array}{c}\text { Support for agronomic, cultural traditions, } \\
\text { local knowledge aspects of in situ } \\
\text { conservation }\end{array}$ \\
\hline
\end{tabular}

${ }^{1}$ Centro de Investigación de Recursos Naturales y Medio Ambiente; ${ }^{2}$ Fomenta de la Vida; ${ }^{3}$ Instituto de Desarrollo y Medio Ambiente; ${ }^{4}$ Intermediate Technolgy Development Group; ${ }^{5}$ Proyecto Andino de Tecnologías Campesinas; ${ }^{6}$ Sociedad Peruana de Derecho Ambiental; 7 Grupo de Investigación y de Extensión de Tecnología Popular. associated with CCTA in in situ projects. ${ }^{b}$ When first began working in Peru. ${ }^{c}$ Associated with PRATEC; other affiliates include Asociación Bartolomé Aripallya- ABA, Asociación Pacha Uyway - APY, and Asociación Wari-AWAY--all based in Ayacucho (See http://www.insitu.org.pe/webinsitu/directorio.htm\#ccta, for names of other affiliates).

such as CESA working in Paucartambo near Cusco (Pérez 1996), PRATEC (PRATEC 1997; Apffel-Marglin 1998), and Urpichallay (Rojas et al. 1999) near Huaraz in Ancash have followed similar practices (Figure 2). Among its various activities, the Instituto de Desarrollo y Medio Ambiente (IDMA) promotes the conservation of biodiversity as part of a broad-based strategy intended to expand and improve organic production of food crops like potatoes in Huánuco and Apurimac (Abancay). The Quechua-Aymara Association for Nature and Sustainable Development, ANDES in Spanish, has been working with farmers located near Cusco (Andersen \& Winge 2008). Part of that work involves CIP repatriating to these growers disease-free seed material developed from native potato varieties originally collected in the six
Quechua communities participating in the project in an effort to preserve the "[...] natural processes of evolution and selection in response to changing conditions [...]" (CIP 2009 , p. 2). Other NGOs such as ADERS (Asociación para el Desarrollo Sostenible)-Perú have emphasized more integrated initiatives linked to market access involving, for example, judicious use of chemical inputs to improve productivity, with those focused on postharvest procedures such as better grading (Bucheli et al. 2009) and processing (ADERS 2007). FOVIDA and its affiliated organization CAPAC-Perú have been involved in similar marketing efforts in Junín, Huancavelica, and Cusco. These include helping groups of small farmers to negotiate and meet contracts (Bernet et al. 2002) with different types of potato processors (Bollo 2008) 


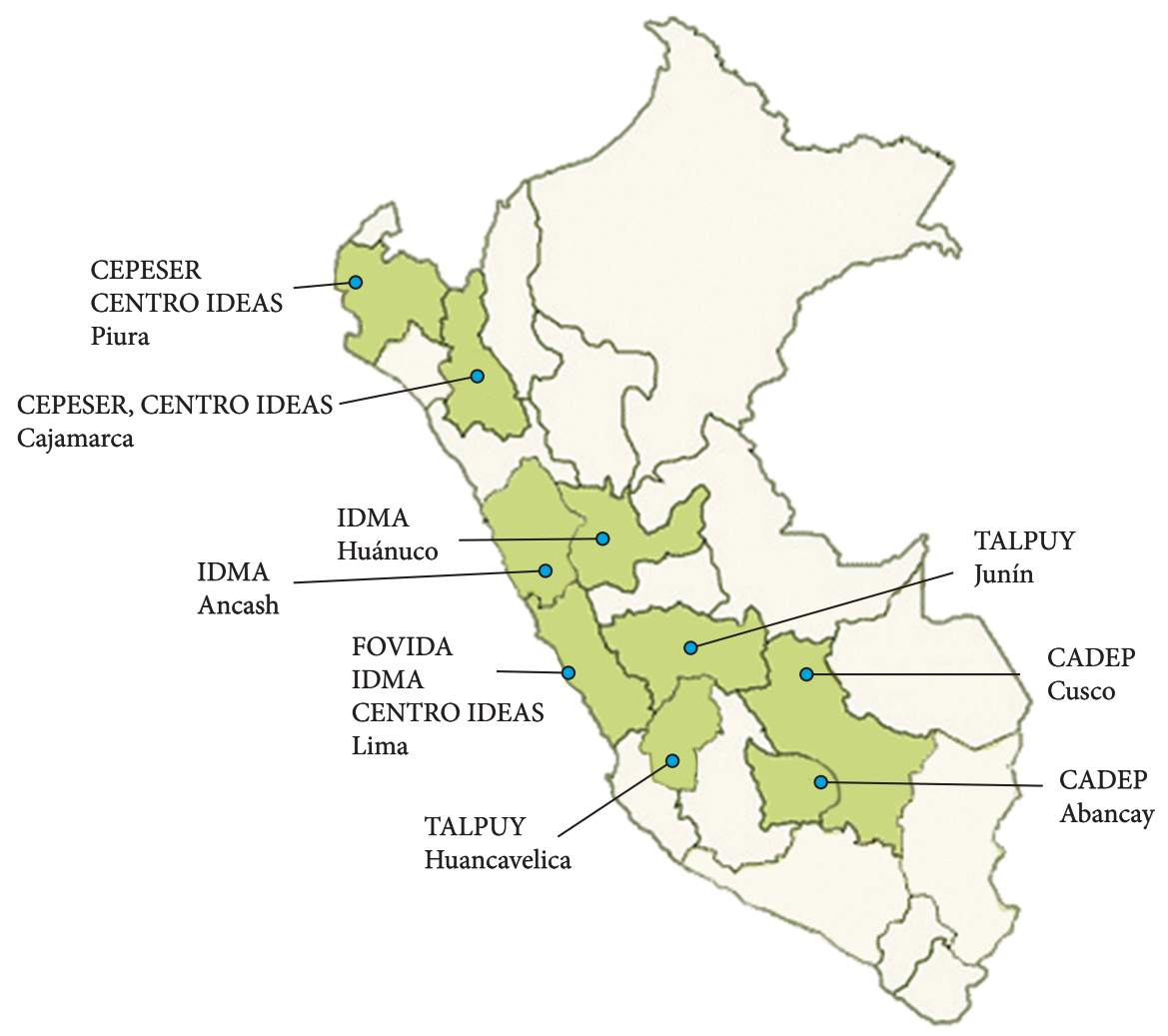

Figure 2. Peru: Location of selected NGO conservation activities.

as well as develop new market outlets (Delgado 2009). Instituto Rural Valle Grande adopted a similar integrated approach in Yauyos in the central highlands but with greater emphasis on conservation for on-farm use or local sale (De Haan 2002) as has ARARIWA near Cusco (Cosio 2006; Ortega 2006; Guzmán 2007) and Centro Internacional de Cooperación para el Desarrollo Agricola (CICDA) in Huancavelica (Baliteau \& Chauchi 2000).

Other NGOs, such as Coordinadora de Ciencia y Tecnología de los Andes (CCTA), focus a good part of their efforts serving as a clearing house for information on in situ conservation activities:

projects, training courses, technical assistance materials, symposia as part of their broader and longstanding commitment to facilitate rural development in the Andes (Velásquez et al. 2001; Guevara \& Parra 2009). NGOs such as IDMA and Sociedad Peruana de Derecho Ambiental (SPDA) devote part of their conservation work to promoting in situ conservation specifically and environmental conservation generally with government officials in local (municipal) or regional offices as well as with national policymakers and multinational organizations so as to include environmental protection in development plans, projects, and laws.

Many of these same NGOs worked together during five years (2001-2006) in the Global Environmental Facility
(GEF)-funded national in situ conservation project that focused on various crops including potatoes (Egúsquiza et al. 2006; INIEA \& MINAG 2006; Ortega 2006). The GEF project was a landmark initiative in terms of the scale (multiple crops in the coast, highlands and Amazon jungle regions, with participation by NGOs, universities, and with a budget of US\$ 5 million) of the effort and the success it had in 1) documenting varieties in different communities (Cosio 2006); 2) raising the sense self-esteem and cultural pride of the farm communities in the process (Guzmán 2007); 3) training young people in conservation awareness and practices; resulting also in 4) sensitizing urban consumers regarding the importance of the conservation efforts of small farmers in general and those involved in production and use of native potato varieties in the highlands in particular with the launching of the National Day of the Potato among other activities (Ordinola et al. 2007a; Chumpitaz 2008; Rocha 2010). Given the sheer scope of the endeavor, the GEF project also suffered from certain limitations including the difficulties of ensuring scientific rigor in the capturing of different types of conservation data under farmer conditions in a number of different localities simultaneously.

In the context of these NGOs initiatives aimed at supporting the continued cultivation of native potato varieties by small-scale producers in centers of native potato production (Canahua et al. 2002), some farmers (referred to as stewards 
or "conservacionistas" or "cuidadores" of biodiversity)--either acting on their own or as part of community-based farmer groups, pursue many of the traditional conservation practices (Andersen \& Winge 2008; Gómez et al. 2008; Tapia 1994, 2008a; see Table 1). Others, like those affiliated with the Potato Park, in addition to practicing the conservation of biodiversity of potato plants are also engaged in conserving the cultural landscape of their environment - implying agrobiodiversity, wild relatives and associated knowledge. That latter activity involves promoting the rights of ownership of these tangible and intangible resources (CIP 2009). In the process, some of these growers or community-based efforts have gradually become well known in particular local farm communities or growing regions (DGCA \& MINAG 2009). Some of these farmers regularly present themselves and their potatoes at seed fairs (Tapia \& Rosas 1993), public gatherings, or events (e.g., National Potato Congresses, Regional Potato Festivals) as stewards of native potato varieties (Tapia 2008a). In so doing, these growers expand their interactions with other growers, their varieties, and their knowledge about these materials. Their network of personal contacts comes to cover a broader geographic area. Others seek to become recognized as "champion" stewards of native varieties based on the number of different accessions that they can display (ITDG 2009).

Some of these stewards are able to carry out these activities through the support of Non-Government Organizations (NGOs), universities, the Ministry of Agriculture, or other organizations (Tapia 2008b). The work of these stewards and the community-based associations to which many belong has recently begun to be officially recognized. The awarding of certificates commending their conservation activities on different occasions such as at the First National Potato Congress (May 2008) and the annual National Day of the Potato (celebrated the last week in May) has been greeted with increasing fanfare and involvement by the private and public sector alike. A flurry of newspaper articles, media reports, exhibitions, and official publications have given additional coverage to the conservacionistas' undertakings (Chumpitaz 2008; Tapia 2008a, 2008b; DGCA \& MINAG 2009). The different award ceremonies have also provided a forum for greater public awareness and given these growers access to policymakers. The conveying of the certificates has also brought the growers non-monetary rewards such as the status and prestige derived from being singled out by the press and public authorities for their conservation efforts.

NGOs' efforts in the conservation of the biodiversity of native potatoes in Peru are also seen as having their own limitations (Table 2). For one, they have limited technical expertise such as in the production and distribution of virus-free native materials. Some observers also contend many of these efforts are too localized and project-limited in scope. In other words, they are promoted and carried out very much on an individual basis, or part of a limited association with organizations that share like-minded objectives and approaches. Furthermore, these efforts are subject to available funding for particular activities without necessarily responding to a local, regional, let alone national consensus view regarding which activities in which locations deserve greatest priority. In addition, their reliance on unpredictable sources of funding mean their activities are subject to abrupt interruptions, scaling back, or even closing down entirely should donor organizations delay the transfer of resources or shift priorities, thereby putting in jeopardy months, if not years of work in the process. Growing concern about funding among some NGOs coincided with the interest of farmers in exploring perceived opportunities for producing and selling products made from native potato varieties heretofore grown exclusively for on-farm consumption or trade in local rural markets.

\section{Companies and Conservation}

While some native potato varieties with exceptional culinary traits or noted for high yields have been traded in the southern Andes for centuries (Zimmerer 1996) and the marketing of native yellow potato varieties in Lima has gone on for over 60 years (Scott 1985), the prospect of purchasing other, more exoitic native potatoes (or products made from these tubers) not seen in major urban markets began to achieve increased attention beginning around 2000 . Growing interest on the part of chefs in the New Andean cuisine combined with a resurgent gastronomic appeal of traditional food commodities produced in the highlands helped generate greater demand for native potatoes generally and the more unusual varieties in particular in major metropolitan markets (Devaux et al. 2006; Ordinola et al. 2007a,b; Meinzen-Dick et al. 2009). A combination of factors contributed to this phenomenon.

Rising real incomes for the vast majority of Peruvian households made new and unusual foods more affordable for more consumers (De Althaus 2007). A booming tourism trade meant foreign visitors, typically with ample disposable income, were arriving in Peru in part looking to try new dishes with exotic ingredients as one aspect of their experience abroad. On the supply side, researchers at CIP and MINAG began evaluating native potato varieties for different traits including consumer preferences for unusual colors and processing characteristics. These technical efforts were also motivated in part by an analysis of secondary data that found a high correlation between those districts with a high incidence of severe poverty and communities with cropping areas above $3,500 \mathrm{~m}$ where little else but native varieties could be grown. This coincidence of interests gradually evolved into a growing array of activities, organizations and enterprises offering support to producers planting native potato varieties that emphasized, but were not restricted to the sale of these tubers as a form of market-driven in situ conservation combined with eradication of absolute poverty (Tables 1 and 2). In the words of Valerie Barbier, founder of a firm selling natural cosmetic products that use organically grown, purple-fleshed native potatoes rich in anti-oxidants 
as a key ingredient for making creams and lotions used for cleansing the skin and preventing wrinkles, her business goals include," [...] improving the quality of life in selected Andean communities and helping maintain biodiversity [...] (author's translation)" (Barbier 2009, p. 4).

Ensuing entrepreneurial endeavors have focused on everything from exotic (i.e., those cultivars heretofore not sold through established marketing channels) native potato varieties sold fresh in boutique-like packets to snack foods (e.g., potato chips), traditional freeze-dried potatoes produced using improved processing techniques, and industrial purées. They also include non-food products like cosmetics. The depth and scope of these commercial activities has varied considerably in terms of: i) the size, history and product mix of the firm; ii) whether it is local, national or international in nature; iii) whether the product is fresh or processed; and iv) whether the postharvest technologies involved are industrial in nature or farmer-based (Tables 5 and 6). In many instances, the launching of these products resulted from strategic alliances between private entrepreneurs, community-based producer associations and the associated NGOs, MINAG and its affiliates such as INIA, and CIP. Such efforts had begun a decade earlier with an emphasis on exports (Fano et al. 1998) or hybrid potatoes (Bernet et al. 2002), but now became focused more on the domestic market, native varieties, and more explicit links to poverty reduction (Ordinola et al. 2009). On-going activities encompass five areas simultaneously: promoting greater consumption and use by working with supermarkets, culinary schools, the association of Peruvian chefs, interested entrepreneurs, and the media to raise the profile and educate the public about the culinary, nutritional, and medicinal attributes of native potatoes (Lau 2008; Maximixe 2008); adding value through developing new processed products (Barbier 2009) or improving traditional techniques (Fonseca 2009); strengthening capabilities of small farmers in contract negotiations with industry while nurturing corporate social responsibility (Thomann et al. 2009); more credible and timely information about new

Table 5. Firms selling native potatoes in Peru: Type, year established, plant location, and product line.

\begin{tabular}{|c|c|c|c|c|}
\hline Firm & Firm type & Established & Plant location & Product line \\
\hline Mishki & Start-up/ private & 2004 & Huancayo & Cosmetics \\
\hline Patcor (Inka Gold) & Start up/ private & 2006 & Huancayo & Snacks \\
\hline Frito Lay & US-based multinational & $1932 / 1994^{1}$ & Lima & Snacks \\
\hline Grupo Gloria & Peru-based multinational & $1941 / 2007^{2}$ & Lima & Food products \\
\hline Agropia & $\begin{array}{c}\text { Farmer organization/ } \\
\text { community based }\end{array}$ & 2007 & Huancavelica & Andean food commodites \\
\hline Aprocultivos & $\begin{array}{c}\text { Farmer organization/ } \\
\text { community based }\end{array}$ & 2007 & Cusco & Andean food commodites \\
\hline $\begin{array}{l}\text { A\&L Exportaciones } \\
\text { y Servicios SAC }\end{array}$ & Start-up/private & 2004 & Lima & Andean food commodites \\
\hline $\begin{array}{l}\text { Consorcio } \\
\text { Los Aymaras }\end{array}$ & $\begin{array}{c}\text { Farmer organization/ } \\
\text { community based }\end{array}$ & 2005 & Puno & Andean food commodites \\
\hline Delinkas & Private & 2007 & Lima, Cajamarca & Food products \\
\hline
\end{tabular}

${ }^{1}$ The Frito company was founded in the US in the 1932; Frito-Lay established operations in Peru in $1994 .{ }^{2}$ Grupo Gloria began in 1941, but established its snack food division in 2007.

Table 6. Firms selling native potatoes in Peru: Products, market focus, and collaborators.

\begin{tabular}{|c|c|c|c|}
\hline Firm & Product & Market focus & Collaborators \\
\hline Mishki & Skin creams, lotions & Domestic/EU & U San Marcos, CIP \\
\hline Patcor (Inka Gold) & Potato chips & Domestic (Lima)/US & U San Ignacio Loyola \\
\hline Frito Lay & Potato chips & Domestic & CAPAC, FOVIDA, CIP \\
\hline Grupo Gloria & Potato chips & Domestic & INIA \\
\hline Agropia & Potato chips & Export(France) & $\begin{array}{c}\text { CICDA; Fair Trade } \\
\text { association, supermarkets Le Clerck } \\
\text { \& Champion }\end{array}$ \\
\hline Aprocultivos & Fresh potatoes & $\begin{array}{l}\text { Local/Cusco Five star } \\
\text { hotels }\end{array}$ & ARARIWA \\
\hline $\begin{array}{l}\text { A\&L Exportaciones y Servicios } \\
\text { SAC }\end{array}$ & $\begin{array}{c}\text { Fresh potatoes, potato } \\
\text { chips }\end{array}$ & Domestic (Lima) & $\begin{array}{l}\text { CAPAC, CIP, MINAG WONG } \\
\text { supermarkets }\end{array}$ \\
\hline Consorcio Los Aymaras & Tunta & $\begin{array}{c}\text { Domestic (Puno, Lima)/ } \\
\text { Bolivia }\end{array}$ & $\begin{array}{l}\text { MINAG, Ministry of Production, } \\
\text { U. Peruana Union, CIP, CIRNMA } \\
\text { Colegio de Nutricionistas del Peru }\end{array}$ \\
\hline Delinkas & $\begin{array}{l}\text { Instant puré from yellow } \\
\text { potatoes }\end{array}$ & Export (EU) & MINAG, CIP, ADERS \\
\hline
\end{tabular}


market outlets (Meinzen-Dick et al. 2009); and, providing technical assistance to farmers regarding everything from efforts to improve yields and grade-outs at harvest to quality requirements of processors and supermarkets. In addition, they have helped farmers secure higher prices and improve their incomes thereby encouraging them to maintain production of native potato varieties (Bucheli et al. 2009).

Early indications are that these various efforts have expanded the market for exoitic native potato varieties beyond the traditional local fairs and farmer-to-farmer exchange. One estimate of the combined volume of these native potato varieties sold through the market annually is on the order of 2,000 mt (metric tonnes) with the prospect of continued expansion in the years ahead (Thomann et al. 2009). No statistics exist on annual production of native potatoes. However, to put the 2,000 mt in context, native varieties are thought to account for some $25 \%$ of annual output, or roughly $900,000 \mathrm{mt}$ according to recent estimates of annual total potato production (DGCA \& MINAG 2009). Nevertheless, it is less clear what percentage of that estimated sub-total represents the over 2,000 exotic native varieties versus the small group $(<10)$ of mainly yellow native potato varieties that have long been grown for sale (Scott 1985) and now account for some 65,000 $\mathrm{mt}$ of potatoes shipped yearly to Lima's wholesale market (Devaux et al. 2010).

Conservation of biodiversity via the market also has its sceptics (Brush 2004) and limitations (Table 2). It remains to be seen whether certified sales of native potato products to markets in Europe or North America will tap into the growing demand for healthier foods in a significant way or be confined to a minor niche market for exotic food stuffs. Furthermore, it is not entirely clear that the current monopoly on supply held by small farmers, noted as a key component of the on-going strategy to improve small-farmers' incomes via the processing and sale of the more exotic native varieties (Meinzen-Dick et al. 2009), will persist should the market for final products eventually prove broader and deeper than is now the case. Some processors already work with larger growers to reduce their transaction costs. Furthermore, while growers do receive higher prices by selling their potatoes through NGO-facilitated private company marketing schemes, preliminary estimates suggest that the support costs required to shepherd small farmers through the production, harvest and sale of native potato varieties to major urban consumer markets and/or to industrial processors are considerable. They preclude charging farmers for these services without significantly affecting the income gains to growers from participating in these activities. In addition, not all native varieties have proven equally attractive as raw material for processing or for sale in fresh form (García Arancibia et al. 2010). These sorts of concerns have prompted interest in other approaches to conservation.

\section{Conservation Via Other Actors and Activities}

Not all producers in the vast, rugged highlands of Peru can participate in the types of programs outlined above. Some growers fall outside on-going projects for conserving biodiversity, for example, due their geographic isolation. Under these circumstances, various alternatives have come up for consideration. These include payment for environmental services and Participatory Crop Improvement (PCI).

The idea of offering payment for environmental services is something relatively new in Peru, but it has attracted increasing interest (Armas et al. 2009). In the specific case of potatoes, it raises questions about who (or whom) would pay for such services? How, where, in what form, to how many producers, and for how long could one envision that such payments form part, albeit perhaps limited and experimental, of an overall portfolio of activities intended to sustain the biodiversity of native potatoes in Peru? One possibility in this regard would be for municipal and regional governments simply to assist farmer organizations in the repatriation of virus-free seed materials of those cultivated native varieties collected in their communities. For wild potato species, another might be to establish nature reserves along the lines of those reserves (e.g. Manu) already set up in other parts of the country for similar reasons. Given the vast numbers of varieties and participants potentially involved combined with the areas required to carry out these activities, some question the operational viability of these proposals in terms of administrative challenges posed, potential cost, unknown effectiveness, and possible unanticipated negative impact of introducing a payment scheme into a system of traditional practices.

Proponents of participatory crop improvement (PCI) consider this approach as another way to facilitate in situ conservation by bringing the benefits of modern crop science to small farmers in marginal areas that up to now have benefited much less than larger growers in more favourable environments from breeding programs, often based in part on germplasm collected from those same isolated locations (Almekinders \& Elings 2001; Brush 2004). Almekinders and Elings (2001) define "marginal areas" as those with variable elevations, soils, climate and socio-economic conditions that induce small farmers to use a variety of crops and varieties to reduce the risks associated with sustaining a livelihood from agriculture. Under those conditions, PCI consists of two variants: participatory varietal selection (PVS) and participatory plant breeding (PPB). In the former, farmers help select new, improved varieties based on a number of criteria in addition to high yields, e.g., taste, cooking time, from a collection of advanced materials. In the latter, farmers participate in the process of developing and selecting new varieties at a much earlier stage. Both approaches have their perceived relative advantages. PVS is easier to implement; PPB enhances the probability of greater adoption. However, to date neither approach has gained widespread acceptance for conserving or breeding potatoes in Peru. Some observers point to the fact that PVS involves growers only after the crosses have already been made and therefore offers them less of an opportunity to establish selection criteria at the more critical initial stages of the process. Others note that PPB requires elaborate experimental designs and increasingly complex field work less compatible with the financial and 
human resources available for conducting such trials in local research organizations.

\section{Conclusions}

In summary, a whole series of actors are engaged in sustaining the biodiversity of Peru's native potato varieties. Although many of the actors are involved with more than one type of conservation activity, each of these actors has its respective principal objectives, approaches, expected outcomes and time-line in terms of when and how they foresee benefits forthcoming from their corresponding efforts. The array of their initiatives in its totality constitutes, de facto, an array of investments-public, private, local, national, international in the conservation of the biodiversity of Peru's native potato varieties (Table 7).

The number of different actors engaged in the conservation of the biodiversity of native potatoes in Peru, their respective

Table 7. A qualitative summary of the conservation of the biodiversity of the potato in Peru.

\begin{tabular}{|c|c|c|c|c|}
\hline \multirow[t]{2}{*}{ Activity/Sub-activity } & \multicolumn{4}{|c|}{ Actor } \\
\hline & Farmer-led & Scientist-led & NGO-led & Company-led \\
\hline \multicolumn{5}{|l|}{ Agronomy } \\
\hline Best traditional agronomic practices & $\mathrm{X}$ & $\mathrm{Y}$ & $\mathrm{X}$ & NA \\
\hline Organic agriculture & $\mathrm{Y}$ & NA & $\mathrm{Y}$ & NA \\
\hline Better use of chemical inputs & $\mathrm{Y}$ & $\mathrm{X}$ & $\mathrm{Y}$ & NA \\
\hline \multicolumn{5}{|l|}{ Seed \& planting material } \\
\hline Seed fairs & $\mathrm{X}$ & NA & $\mathrm{Y}$ & NA \\
\hline Seed exchange & $\mathrm{X}$ & $\mathrm{Y}$ & $\mathrm{X}$ & NA \\
\hline Communal seed banks & $\mathrm{Y}$ & $\mathrm{Y}$ & $\mathrm{Y}$ & NA \\
\hline Reintroducing virus-free material & $\mathrm{Y}$ & $\mathrm{Y}$ & $\mathrm{Y}$ & NA \\
\hline \multicolumn{5}{|l|}{ Documentation, training, education } \\
\hline Local knowledge of native varieties & $\mathrm{X}$ & $\mathrm{Y}$ & $\mathrm{X}$ & NA \\
\hline Reaffirmation of local culture & $\mathrm{X}$ & NA & $\mathrm{Y}$ & NA \\
\hline \multicolumn{5}{|l|}{ Participatory Crop Improvement } \\
\hline Participatory varietal selection & $\mathrm{Y}$ & $\mathrm{Y}$ & NA & NA \\
\hline Participatory plant breeding & NA & NA & NA & NA \\
\hline \multicolumn{5}{|l|}{ Ex situ conservation } \\
\hline In vivo & NA & $\mathrm{X}$ & NA & NA \\
\hline In vitro & NA & $\mathrm{X}$ & NA & NA \\
\hline True seed & NA & $\mathrm{Y}$ & NA & NA \\
\hline Cryo-preservation & NA & $\mathrm{Y}$ & NA & NA \\
\hline Frozen DNA & NA & $\mathrm{Y}$ & NA & NA \\
\hline Back-up gene banks & NA & $\mathrm{Y}$ & NA & NA \\
\hline \multicolumn{5}{|l|}{ Marketing practices for existing products } \\
\hline Better supply chain co-ordination & $\mathrm{Y}$ & NA & $\mathrm{Y}$ & $\mathrm{Y}$ \\
\hline New market outlets & $\mathrm{Y}$ & $\mathrm{Y}$ & $\mathrm{Y}$ & $\mathrm{Y}$ \\
\hline Improved grading and packaging & $\mathrm{Y}$ & $\mathrm{Y}$ & $\mathrm{Y}$ & $\mathrm{Y}$ \\
\hline \multicolumn{5}{|l|}{ New product development } \\
\hline Cosmetics & $\mathrm{Y}$ & $\mathrm{Y}$ & NA & $\mathrm{Y}$ \\
\hline Potato chips & $\mathrm{Y}$ & $\mathrm{Y}$ & $\mathrm{Y}$ & $\mathrm{X}$ \\
\hline $\begin{array}{l}\text { Premium packaging/promotion for sale of } \\
\text { exotic tubers in fresh form }\end{array}$ & $\mathrm{Y}$ & $\mathrm{Y}$ & $\mathrm{Y}$ & $\mathrm{Y}$ \\
\hline $\begin{array}{l}\text { Feasability studies for new products, e.g. } \\
\text { instant purée }\end{array}$ & NA & $\mathrm{Y}$ & $\mathrm{Y}$ & $\mathrm{Y}$ \\
\hline \multicolumn{5}{|l|}{ Improved traditional processed products } \\
\hline Establish legal product quality norms & NA & $\mathrm{Y}$ & $\mathrm{Y}$ & NA \\
\hline Improve processing techniques & $\mathrm{Y}$ & $\mathrm{Y}$ & $\mathrm{Y}$ & NA \\
\hline Expand market outlets via testing, promotion & NA & $\mathrm{Y}$ & $\mathrm{Y}$ & $\mathrm{Y}$ \\
\hline \multicolumn{5}{|l|}{ Gastronomy \& tourism } \\
\hline Food fairs, demonstrations, cook books & NA & $\mathrm{Y}$ & $\mathrm{Y}$ & $\mathrm{Y}$ \\
\hline Promotion of gastronomic tourism & NA & NA & $\mathrm{Y}$ & $\mathrm{Y}$ \\
\hline Modifying training programs for chefs & NA & NA & $\mathrm{Y}$ & $\mathrm{Y}$ \\
\hline
\end{tabular}

Legend: $\mathrm{X}=$ Frequent; $\mathrm{Y}=$ Few; NA = Not applicable. 
areas of engagement and the technologies employed have all expanded and diversified over time. This trend certainly suggests that the sum total of efforts to maintain the biodiversity of potatoes has also grown although precise figures are hard to calculate given the complexities involved.

Given this biodiversity portfolio and in the wake of a growing sense of urgency about the need for not just more, but more optimal conservation efforts in the wake of climate change, a series of questions emerge about these efforts including what are the principal lessons learned to date on such diverse topics as: The possible do's and don'ts of establishing and maintaining a community genebank for repatriated native varieties? How to lower costs and increase effectiveness when implementing and maintaining a regional ex situ collection? How to implement a system such as bar coding so as to minimize the risk of mixtures of materials held in ex situ conservation? What do we know now that we didn't before about negotiating processing contracts on behalf of farmer communities? Might the market development process be enhanced and accelerated by taking fuller advantage of the experience that others have acquired in this same type of work in Peru and elsewhere in the Andean region (see, e.g., Ferris et al. 2006)? How can local knowledge about conservation of native varieties be more rapidly documented and disseminated? How can the concept of a research and development oriented genebank (Bamberg \& Del Rio 2007) be broadened operationally to include collecting, characterizing, and capitalizing on local knowledge? How can a national documentation system on biodiversity efforts be approximated via links between websites of the different actors to reduce the transaction costs associated with trying to capitalize and build on previous experiences across different parts of a country as big and diverse as Peru?

A related set of issues is raised by De Haan (2009) regarding which of the different NGO in situ conservation initiatives (e.g., seed fairs, communal seed banks, capacity building, etc.) have had the (greatest) impact. One might also inquire about which show the greatest promise going forward and the most appropriate mechanisms for facilitating replication. A similar assessment in the case conservation efforts via the market might make the process of broadening the number of beneficiaries, estimated (Meinzen-Dick et al. 2009) to be around 4,000 farm families, more effective and efficient. It might also help eventually to confront inevitable trade-offs in policy, priorities and projects faced by national policymakers, international donors, and regional governments, among others, in a more fully informed manner (Wale et al. 2009).

Among the unfinished tasks at hand to sustain the overall effort are: 1) registering Peru's native potato varieties before the recognized, official legal authority in that domain (Paredes Piana 2010); said registration is independent of that done in order to become eligible for multiplication as certified seed; 2) continue to register native potato varieties with the government entity in charge of supervising certified seed production, so that as they become legally documented, they are eligible for multiplication as certified seed; 3 ) greater emphasis on the evaluation of not only the technical, but also the economic feasibility of new and/or improved products using native potato varieties before committing scarce public and/or international donor funds to such undertakings; 4) proceed to document and disseminate information on the various production, postharvest and utilization traits of the documented native potato varieties so that they be can be more effectively utilized; 5) complete the national registry of native varieties being undertaken by INIA; 6) publicize more extensively the results achieved to date in order to, among other things, facilitate greater synergies among both actual and potential participants in the aforementioned activities; and 7) in the context of these developments and the series of existing and about-to-be-signed trade agreements, aggressively seek out ways to institutionalize the process of national consultation on conserving the biodiversity of native potato varieties as part of an overall strategy for the potato sector in the years ahead.

\section{Acknowledgements}

I would like to thank Carlos Arbizu, Steve Brush, Rolando Egúsquiza, Stef de Haan, Rene Gomez, Daniela Horna, Enrique Mayer, Alberto Salas, Maria Scurrah, Hubert Zandstra, and two anonymous reviewers for commenting on earlier versions of this paper, and Franklin Plasencia for the Figures.

\section{References}

Asociación para el Desarrollo Sostenible - ADERS, 2007. Estudio de factibilidad para la instalación de una planta procesadora para papa nativa para la obtención de papa instantánea. Processed. Lima: ADERS- Perú.

Agriculture \& Agri-Food Canada - AAFC, 2007. Canadian potato-situation and trends 2006-07. Ottawa: AAFC.

Almekinders CLM \& Elings A, 2001. Collaboration of farmers and breeders: Participatory crop improvement in perspective. Euphytica, 122(2):425-436. http://dx.doi. org/10.1023/A:1017968717875

Almeyda Camani MA, 2004. Producción y comercialización de papas nativas en seis comunidades campesinas de Calca y Urubamba del Departamento del Cusco. [Tesis]. Cusco: Universidad Nacional San Antonio Abad.

Alteri M \& Merrick L, 1987. In situ conservation of crop genetic resources through maintenance of traditional farming systems. Econ Botany, 41(1):86-96. http://dx.doi. org/10.1007/BF02859354

Andersen R \& Winge T, 2008. Success stories from the realization of farmers' rights related to plant genetic resources for food and agriculture. FNI report 4/2008. Lysaker: The Fridtjof Nansen Institute.

Antezana I et al., 2005. Poverty in potato producing communities in the central highlands of Peru. Berlin: Humboldt-Universitat $\mathrm{zu}$ Berlin and the Center for Advanced Training in Rural Development. 
Apffel-Marglin F, 1998. Introduction: Knowledge and life revisited In: Apffel-Marglin F \& Proyecto Andino de Tecnologías Campesinas - PRATEC (Eds.). The spirit of regeneration. Andean culture confronting western notions of development. London: Zed Books. p. 1-50.

Armas A et al., 2009. Pagos para servicios ambientales para la conservación de bosques en la Amazonía peruana: un análisis de viabilidad. Lima: Servicio Nacional de Áreas Naturales Protegidas por el Estado - SERNANP, Ministerio de Ambiente MINAM.

Bamberg JB \& Del Rio AH, 2007. The canon of potato science: 1. Genetic diversity and genebanks. Potato Res, 50:207-210. http://dx.doi.org/10.1007/s11540-008-9035-z

Barbier V, 2009. La industria de cosméticos de papa. In: Seminar La Papa:Tesoro de los Andes. Valor agregado y comercialización; 2009; La Molina. La Molina: National Agrarian University.

Baliteau S \& Chauchi C, 2000. Diagnostico agrario de una pequeña región de los Andes Centrales en el Peru: Distrito de Yauli (Departamento de Huancavelica). Practica de fin de estudio Marzo-Agosto. Processed. Lima: Centro Internacional de Cooperación para el Desarrollo Agricola - CICDA.

Bernet T et al., 2002. El reto de vincular a los pequeños productores de papa con la agroindustria. Revista LatinoAmereica de la Papa, 13(1):1-23.

Bollo G, 2008. Negocio de hojuela y bocaditos a base de papas nativas. In: I Congreso Nacional de la Papa; 2008; Huancayo. Available from: <www.minag.gob.pe >.

Bradshaw J, Bryan GJ \& Ramsay G, 2006. Genetic resources (including wild and cultivated Solanum species) and progress in their utilization in potato breeding. Potato Research, 49:49-65. http://dx.doi.org/10.1007/s11540-006-9002-5

Brush S, 1992. Farmers' rights and genetic conservation in traditional farming systems. World Development, 20(11):16171630. http://dx.doi.org/10.1016/0305-750X(92)90018-Q

Brush S, 2004. Farmers' bounty. Locating crop diversity in the contemporary world. New Haven: Yale University Press. http://dx.doi.org/10.1016/0304-3878(92)90044-A

Brush S, Taylor J \& Bellon M, 1992. Technology adoption and biological diversity in Andean potato agriculture. Journal of Development Economics, 39:365-387.

Bucheli B et al., 2009. Estudio de caso: Evaluación de la intervención del Proyecto INCOPA/ ADERS en Huanuco. Social Science working paper No. 2009-2. Lima: International Potato Center - CIP.

Caillaux J, 2005. Acceso a los recursos genéticos. In: Ferro P \& Ruiz M (Eds.). ¿Comoprevenir la biopiratería en el Perú? Lima: Sociedad Peruana de Derechos Ambientales - SPDA. p. $36-47$.

Canahua A et al., 2002. Gestión del espacio agrícola en papa y quinoa en las comunidades de Puno. In: Pulgar-Vidal M, Zegarra E \& Urrutia J (Eds.). Perú: el problema agrario en debate. Lima: SEPIA. p. 286-316.

Canora J et al., 2007. Modelo de gestión para el desarrollo comercial de la papa nativa: Análisis y propuesta de implementación para la comunidad de Pazos (Huancavelica). [Tesis]. Lima: Universidad Escuela de Administración de Negocios para Graduados.
Chiu C \& Guevara D, 2005. Andean treasure: Naturally good food. Plan de negocios. Lima: Universidad del Pacifico.

Christiansen J, 1967. El cultivo de la papa en el Perú. Lima: Editorial Jurídica.

Chumpitaz M, 2008. Papa grande. Somos (El Comercio) 1107:30-41.

Cosio P, 2006. Variabilidad de papas nativas en seis comunidades de Calca-Urubamba. Cusco: Asociación ARARIWA.

De Althaus J, 2007. La revolución capitalista en el Perú. Lima: Fondo de Cultura Económica.

De Haan S, 2009. Potato diversity at height. Multiple dimensions of farmer-driven in situ conservation in the Andes. [Tesis]. Wageningen: Wageningen University.

De Haan S et al., 2002. Uso sostenible de recursos fitogenéticos andinos en el Nor-Yauyos. Programa APGEP-SENREM. Lima: Convenio United States Agency for International Development - USAID, Consejo Nacional del Ambiente - CONAM.

De la Piedra C, Raffo F \& Saba N, 2004. Proyecto piloto para la comercialización del puré de papas nativas. Master's Tesis. Lima: CENTRUM, Centro de Negocios de la Pontificia Universidad Católica del Perú.

Del Castillo L, 2004. Diversidad biológica y biopiratería. Debate Agrario, 37:23-38.

Delgado O, 2009. El Comercio Mayorista. In: Seminar La Papa: Tesoro de los Andes. Valor agregado y comercialización; 2009; La Molina. La Molina: National Agrarian University.

Devaux A et al., 2006. Papa Andina: Innovación para el desarrollo en los Andes, 2002-2006. Lima: International Potato Center - CIP.

Devaux A et al. (Eds.), 2010. El sector papa en la región andina. Diagnostico y elementos para una visión estratégica (Bolivia, Ecuador y Perú). Lima: International Potato Center CIP.

Dirección General de Competitividad Agraria - DGCA \& Ministerio de Agricultura - MINAG, 2009. Cadena productiva papa. Boletín 3 (Junio). Lima: DGCA-MINAG.

Egúsquiza R, Mendoza Y \& Salirras E, 2006. Amenazas y planes de mitigación de cultivos nativos ysus parientes silvestres. Conservación in situ de la agrobiodiversidad Andino-Amazónica: Sistematización de factores clave. Proyecto conservación in situ de cultivos nativos y sus parientes silvestres. Lima: Programa para el Desarrollo de las Naciones Unidas - PUND, Gobierno del Perú, Instituto para la Investigación de la Amazonía Peruana - IIAP.

Fano $\mathrm{H}$ et al., 1998. Experiencias de exportación de la papa amarilla peruana. Documento de trabajo No. 1998-3. Lima: CIP, Asociación de Exportadores - ADEX, United States Agency for International Development - USAID.

Ferris S et al., 2006. Strategic paper: a participatory and area-based strategy for rural agroenterprise development. Good practice guide 1. Cali: Centro Internacional para Agricultura Tropical - CIAT.

Fonseca C, 2009. Aprovechando la biodiversidad de la papa para vincular a productores: La experiencia con la papa deshidratada de los andes. In: Seminar La Papa: Tesoro de los Andes. Valor agregado y comercialización; 2009; La Molina. La Molina: National Agrarian University. 
Fuentes C et al., 2009. Planta de puré instantáneo de papas nativas en Cajamarca. Gerencia Global 11. Lima: Universidad Escuela de Administración de Negocios para Graduados - ESAN.

García Arancibia S et al., 2010. Desarrollo de papas nativas con aptitud industrial. Investigación y producción de semillas, experiencias de Mr Chips- Grupo Gloria. In: Cuesta X et al. (Eds.). Congreso internacional de investigación y desarrollo de papas nativas. Quito: Instituto Nacional de Investigaciones Agropecuarias. p. 55-56.

Gómez R et al., 2008. Papas nativas del Perú. Lima: Ministerio de Agricultura - MINAG.

Graber E, 1974. Potato supply, demand and marketing in central Peru. Occasional paper No. 6. Lima: Iowa State University.

Guenthner J, 2001. The international potato industry. Cambridge: Woodhead.

Guevara J \& Parra F, 2009. Parientes silvestres de plantas nativas cultivadas andinas (Perú): Los Sachas. Lima: Coordinadora de Ciencia y Tecnología de los Andes - CCTA.

Guzmán Y, 2007. ¿Devuelta al mundo al revés?: Repensando el Perú al partir de sus diversidades. Proyecto conservación in situ de cultivos nativos y sus parientes silvestres. Lima: Instituto para la Investigación de la Amazonía Peruana - IIAP.

Hausmann R \& Klinger B, 2008. Growth diagnostics in Peru. Faculty research working paper series \#08-062. Cambridge: Harvard Kennedy School.

Herrera J et al., 1994. Perspectivas para el desarrollo agroindustrial de la papa en el Perú. Debate Agrario, 19:67-86.

Hijmans R, 2004. Effects of climate change on the weather and implications for global production. In: Proceedings of the 5th World Potato Congress; 2004; Kunming, China. Charlottetown : World Potato Congress.

Huaman Z \& Schmiediche P, 1991. The importance of ex situ conservation of germplasm: A case study. Diversity, 7(1-2):68-69.

Huaman Z \& Schmiediche P, 1999. The potato genetic resources held in trust by the International Potato Center (CIP) in Peru. Potato Research, 42:413-426. http://dx.doi.org/10.1007/ BF02358158

Instituto Nacional de Investigación Agraria - INIA \& Ministerio de Agricultura - MINAG, 2002. Estrategia nacional de desarrollo de la innovación tecnológica agraria y agroindustria en el Perú. Lima: INIA-MINAG.

Instituto Nacional de Investigación y Extensión Agraria - INIEA \& Ministerio de Agricultura-MINAG, 2006. Conservación in situ de cultivos nativos y parientes silvestres. Informe de cierre. Sitios objetivo del proyecto: Altiplano y Sierra Sur. Parte I. Lima: INIEA-MINAG.

Intermediate Technology Development Group - ITDG, 2009. Memoria 2007-09: Tecnologías desafiando la pobreza. Lima: ITDG. Available from: <http://www.itdg.org.pe> .

International Potato Center - CIP, 1972. Annual report. Lima: CIP. p. 5-15.

International Potato Center - CIP, 1990. Annual report. Lima: CIP. p. 7-13.

International Potato Center - CIP, 2009. CIP's genebank. Lima: CIP.
Lau M, 2008. Papa pre-fita congeladas, lavadas, seleccionadas y empacadas: La experiencia de autoservicios WONG. In: I Congreso Nacional de Papa; 2008; Huancayo. Available from: <www.minag.gob.pe>.

Maximixe, 2008. Factores determinantes para el incremento del consumo de papa en el Perú. Síntesis de los resultados. Lima: Maximixe. Available from: <www.minag.gob.pe>.

Mayer E, 2002. The articulated peasant. Boulder: Westview.

Mayer M, Holle M \& Salas A, 2005. Los ingredientes de la cocina en el Perú andino. In: I Álvarez (Ed.). Desde los Andes al mundo, sabor y saber. Lima: Universidad de San Martín de Porres. p. 327-356.

Meinzen-Dick R, Deveaux A \& Antezana I, 2009. Underground assets: potato diversity to improve the livelihoods of the poor. International Journal of Agricultural Sustainability, 7(4):235-248. http://dx.doi.org/10.3763/ijas.2009.0380

Meléndez Simoni RD et al., 2008. Planta de puré de papa nativa instantánea en Cajamarca: Análisis y diagnostico del plan de negocios. [Tesis]. Lima: Universidad Escuela de Administración de Negocios - ESAN.

Mix-Wagner G, 1999. The conservation of potato cultivars. Potato Research, 42:427-436. http://dx.doi.org/10.1007/ BF02358159

Morote M et al., 2009. Caracterización morfológica y evaluación de estabilidad de rendimiento y calidad culinaria de papa nativa. In: II Congreso Nacional de la Papa; 2009; Ayacucho. Available from: <www.minag.gob.pe $>$.

Murakami Y, 2007. Perú en la era del chino. Lima: Instituto de Estudios Peruanos and the Center for Integrated Area Studies, Kyoto University.

Ochoa C, 1955. Expedición colectora de papas al norte del Perú. Biota, (3-4):47-64.

Ordinola M et al., 2007a. Promoviendo innovaciones con los actores de la cadena y revalorizar la biodiversidad de la papa. El desarrollo y aplicación del enfoque participativo de cadenas productivas en el Perú. Lima: International Potato Center - CIP.

Ordinola M, Bernet T \& Manrique K, 2007b. T'ikapapa: Vinculando consumidores urbanos y pequeños productores andinos con la biodiversidad de la papa. Lima: International Potato Center - CIP.

Ordinola M et al., 2009. Generando innovaciones para el desarrollo competitivo de la papa en el Perú. Lima: International Potato Center - CIP.

Ortega R, 2006. Conservación in situ de los cultivos nuestros y sus parientes silvestres (Sistemización de la experiencia del proyecto). Cusco: Asociación ARARIWA.

Paredes Piana C, 2010. La importancia de la papa en la seguridad alimenticia en el Perú y en el mundo. In: $X X V$ Congreso de la Asociación Latinoamericana de la Papa; 2010; Cusco. Available from: <http://www.alap2010.com/ Presentacion\%20ALAP.pdf $>$.

Pérez L, 1996. Crianza de la papa en Paucartambo, Cuzco. Cusco: Centro de Servicios Agropecuarios - CESA.

Pilares VH, 1993. Evaluación de los sistema de papa nativa en 4 comunidades de Colquemarca. [Tesis]. Cusco: Universidad Nacional San Antonio Abad. 
Prain G, 1993. Mobilizing local expertise in plant genetic resources research. In: De Boef W, Amanor K \& Wellard $\mathrm{K}$ (Eds.). Cultivating knowledge. Genetic diversity, farmer experimentation and crop research. London: Intermediate Technology Publications. p. 102-110.

Proyecto Andino de Tecnologías Campesinas - PRATEC, 1997. Los caminos andinos de las semillas. Lima: PRATEC.

Proexpansión, 2008. Análisis y diagnóstico de la papa en el Perú. Processed. Lima: Proexpansión.

Risi J, 2009. Contribución del INIA a la generación de nuevas variedades de papa en los últimos 30 años. In: II Congreso Nacional de la Papa; 2009; Ayacucho. Available from: $<$ www.minag.gob.pe>.

Rocha A, 2010. Cosecha de Diversidad. SOMOS (El Comercio), 1204:16-22.

Rojas MB et al., 1999. Así converso con mis semillas. La agrobiodiversidad de la cuenca del Marcará: Una perspectiva campesina. Huaraz: Urpichallay.

Scott G, 1985. Markets, myths and middlemen. Lima: International Potato Center - CIP.

Scott G, 2002. Maps, models and muddles: world trends and patterns in potato revisited. Potato Research, 45: 45-77. http://dx.doi.org/10.1007/BF02732218

Scott G, 2010. Growth rates for potatoes in Latin America in comparative perspective: 1961-07. American Journal of Potato Research, published online.

Scott G, Rosegrant M \& Ringler, C. 2000. Roots and tubers for the 21st century: Trends, projections, and policy options. Food, Agriculture, and the Environment Discussion Paper 31. Washington: International Food Policy Research Institute - IFPRI, International Potato Center - CIP.

Segura D, 2002. Evaluación de la potencialidad funcional en 15 genotipos de papa nativa. Lima: Universidad Nacional Agraria-La Molina.

Spooner D et al., 2005. A single domestication for potato based on multilocus amplified fragment length polymorphism genotyping. PNAS, 102:14694-14699. PMid:16203994. PMCid:1253605. http://dx.doi.org/10.1073/pnas.0507400102

Sutherland WJ et al., 2009. One hundred questions of importance to global biological diversity. Conservation Biology, (23)3: 557-567. PMid:19438873. http://dx.doi. org/10.1111/j.1523-1739.2009.01212.x

Tapia M, 1994. Conservación y uso de los recursos genéticos andinos para un desarrollo sostenido. In: Dancourt O, Mayer E \& Monge C (Eds.). Perú: El problema agrario en debate. Seminario Permanente de Investigación Agraria (SEPIA) V. Lima: SEPIA. p. 535-550.

Tapia M, 2008a. Las papas nativas en el Perú: Talleres regionales con agricultores conservacionistas de las papas nativas. Processed. Lima: Ministerio de Agricultura - MINAG.
Tapia M, 2008b. Las papas nativas en el Perú. Origen, distribución y potencial. Processed. Lima: Ministerio de Agricultura - MINAG.

Tapia M \& Rosas A, 1993. Seed fairs in the Andes: a strategy for local conservation of plant genetic resources. In: De Boef W, Amanor K \& Wellard K (Eds.). Cultivating knowledge. Genetic diversity, farmer experimentation and crop research. London: Intermediate Technology Publications. p.111-118.

Tay D, 2009. CIP genetic resources program: A model genebank. In: 15 Triennial Symposium of the International Society for Tropical Root Crops - ISTRC; 2009; Lima. Available from: $<$ http://www.cipotato.info $>$.

Ten Kate K \& Laird S, 1999. The commercial use of biodiversity: access to genetic resources and benefit sharing. London. Earthscan Publications Ltd.

Thomann A et al., 2009. Native potato value chain and poverty reduction: Innovation around corporate social responsibility (CSR). In: International Potato Center - CIP. Annual Review. La Molina, Lima: International Potato Center - CIP. Available from: $<$ http://www.cipotato.org $>$.

United Nations Conference on Environment and Development - UNCED, 1992. Convention on biological diversity. Geneva: UNCED.

Universidad Nacional Agraria- La Molina - UNALM, 2009. Boletín informativo 1 (Agosto). Subproyecto: Determinación de la magnitud e importancia relativa de los factores ambientales en la calidad de las papas nativas cultivadas en la Región Huánuco. Lima: UNALM.

Urrunaga RM, 2002. Estudio etnobotánica de los parientes silvestres de la papa, oca y olluco en el Cusco. Cusco: Universidad Nacional San Antonio Abad.

Velásquez D, Torres J \& Gianella T, 2001. Conservación in situ de la agrobiodiversidad: la experiencia de la CCTA. Lima: Coordinadora de Ciencia y Tecnología de los Andes - CCTA. Cultivos y Saberes no 8. Available from: $<$ http://www.ccta.org. pe/uploads/intranet_proyectos/0748734001240433150.pdf>.

Wale E, Chishakwe N \& Lewis-Lettington R, 2009. Cultivating participatory policy processes for genetic resources policy: Lessons from the Genetic Resources Policy Initiative (GRPI) project. Biodiversity and Conservation, 18:1-18. http:// dx.doi.org/10.1007/s10531-008-9444-y

Zegarra E \& Tuesta J, 2008. Impacto del incremento de precios de los alimentos en la población vulnerable del Perú. Informe final. Lima: Grupo de Análisis para el Desarrollo - GRADE.

Zimmerer K, 1996. Changing fortunes. Biodiversity and peasant livelihood in the Peruvian Andes. Berkeley: University of California Press.

Zimmerer K \& Douches D, 1991. Geographical approaches to crop conservation: the partitioning of genetic diversity in Andean potatoes. Economic Botany, 45(2):176-189. http:// dx.doi.org/10.1007/BF02862046

Received: October 2010

First Decision: December 2010

Accepted: March 2011 